\title{
PERFORMANCE OF ARABIC EDUCATION LECTURERS IN DEVOTION OF LANGUAGE LEARNING
}

\author{
Muhammad Qodri \\ Universitas Islam Negeri Sulthan Thaha Saifuddin Jambi, Indonesia \\ Jl. Arif Rahman Hakim No. 111, Kec. Telanaipura, Kota Jambi, 36361, Indonesia \\ Corresponding E-mail: mubammadqodri@uinjambi.ac.id
}

\begin{abstract}
This article aims to find out how the performance of lecturers in designing, implementing and evaluating learning language proficiency courses. This article uses a descriptive qualitative approach. data collection through interviews, observation, and documentation. Data collected using snowball sampling techniques and data collected were analyzed through the steps of data reduction, data presentation, and drawing conclusions. The findings of this article are: performance of Arabic education lecturers faculty of Tarbiyah in devotion of language learning that lecturer has not maximized the potential in giving lectures, coupled with the preparation of SAP courses that are lacking this is seen in: 1) the design of learning made by lecturers listening and reading in the form of SAP, only briefly explains about several components, namely the identity of the course, learning outcome indicators, lecture method, assessment, and bibliography, mentions several reading sources used in the listening learning process and reading; 2) the implementation of learning include: preliminary activities, core activities, and closing activities; 3) the evaluation of learning outcomes is an activity of measuring the level of success and ability of students in the learning process.
\end{abstract}

Keywords: $\quad$ Arabic lecturer, lecturer performance, Arabic education, language learning devotion

\section{Introduction}

The performance of lecturers in the implementation of learning can be determined at a level through their competence in carrying out the tasks in the performance. Lecturer performance in this learning has a large influence and can determine the level of quality of graduates. The lecturers' pedagogical competencies in learning include the ability and skills to design learning, develop and implement learning strategies, evaluate and perfect learning. The learning design basically functions to 1) strengthen the learning process, 2) know immediately the success rate of the learning process, 3) increase the confidence and enthusiasm of students, 4) 
ensure the achievement of instructional and institutional goals, and 5) achieve learning effectiveness.

The performance of lecturers in learning includes three major components, namely the skills in designing, implementing and evaluating learning. At least there are several reasons underlying the discussion of the performance of lecturers in this learning. According to Davis, the task of teaching is a professional activity that requires high-level skills and includes making decisions intended to facilitate the teaching and learning process, to improve the ability and acquisition of student learning outcomes based on predetermined goals. Furthermore, according to Davis, lecturers who function as learning designers are required to be able to realize their performance well in this learning process. ${ }^{1}$

From the description above, it can be seen that every lecturer needs to show the right decisions, such as what to do, who does it, how to do it, and more importantly why it needs to be done. The accuracy in making decisions on these problems will have a positive impact on the performance of lecturers in learning. To be able to make the right decisions, lecturers need to have an adequate knowledge base on the characteristics of students, theories and principles of learning, design, and development of learning systems, selection of effective learning methods, assessment of student learning outcomes, problems that may be faced, and strategies in mitigating it. $^{2}$

The observations of researchers as PBA lecturers at the Tarbiyah and Teaching Faculty of UIN STS Jambi, language proficiency courses (listening and reading) which have been fostered by several lecturers have been running on their own so that they realize their performance themselves. self with the characteristics of each performance. The design, implementation, and evaluation of these courses vary from one lecturer to another lecturer, even though they hold the same subject. This uniqueness is the reason for the need to be investigated, to provide a description of each performance in learning this language proficiency course, as well as expressing the underlying arguments decided and carried out by each lecturer.

Determination of tarbiyah and teacher faculties, as well as language proficiency courses as the object of this research, besides because the researchers themselves are lecturers in the faculty, also because there has not been a significant change in learning that has an impact on improving quality in the learning process. Therefore, as a first step, it is necessary to have a scientific description of the performance of lecturers in learning this language proficiency course, so that the lecturers can be motivated to further improve the quality of their performance in the whole series of learning.

\footnotetext{
${ }^{1}$ Hamzah B. Uno, Profesi Kependidikan, (Jakarta: Bumi Aksara, 2008), 77-80.

2 Wor. K. Davis, The Management of Learning, (London: McGraw Hill Book Company, 1971), 114.
} 


\section{Theoretical Framework}

\section{Lecturer Performance in Learning}

Performance according to the understanding expressed by experts is basically the same. The difference is only found in their different perspectives. This definition of performance is nothing but the translation is performed. According to Webster that "performance is the ability to perform; capacity to achieve the desired result". ${ }^{3}$ According to Robert that "performance is put out derived from processes, human or otherwise". From these two definitions can be drawn an understanding that performance is the ability to do something to achieve a predetermined goal or a result of the implementation of a person's work process.

Performance is a decisive mean in achieving the goals of an institution or a company; however, this is not easy to do, because many factors affect the high and the low performance. ${ }^{5}$ Syafruddin argues that performance is an ability to carry out tasks or work in accordance with the attitudes, knowledge and skills and motivation of employees. 6 The characteristics of the performance in question are carrying out tasks in accordance with the expectations of an organization that they embrace, using available office equipment, having high enthusiasm, having good cooperative relations with superiors as well as with colleagues, can overcome problems related to routine tasks carried out every day.

Performance is one's level of success in executing a job at a certain period. Performance is defined as the ability to work in terms of quality and quantity. This means that the performance is a feat achieved by a person working both in quality and quantity that are served by an employee in performing their duties in accordance with the responsibilities given to him. Relation to lecturer profession, the lecturer's performance can be interpreted as a result of the quality and quantity of work achieved a lecturer in implementing the Tri Dharma University that includes education and teaching, research, and devotion to the public in accordance with the responsibilities given to him. $^{8}$

Based on the description above, it can be understood that performance is all the behavior of a person in carrying out the functions and duties of a job assigned to him. In connection with this understanding, what is meant by the performance of a

${ }^{3}$ Noah Webster, Websters's New Twentieth Century Dictionary of English Language, (London: William Collins Publisher, 1980), 156.

${ }^{4}$ Robert S.Zais, Curriculum Principles, and Foundation, (Newyork: Harper \& Row Publisher, 1976), 84.

${ }^{5}$ Yusrizal, "Performance Assessment of State Senior High School Teachers Aged 56 Years and Above", International Journal of Instruction, Vol.11, No.1, 2018, 38.

${ }^{6}$ Syafruddin Nurdin, Guru Profesional dan Implementasi Kurikulum, (Jakarta: Ciputat Pers, 2002), 42.

7 Arif Partono Prasetio, 'Lecturers' Professional Competency and Students' Academic Performance in Indonesia Higher Education", International Journal of Human Resource Studies, Vol. 7, No. 1, 2017, 88 .

8 Suryaman, "Indonesian Private University Lecturer Performance Improvement Model to Improve a Sustainable Organization Performance", International Journal of Higher Education, Vol. 7, No. 1, 2018, 61. 
lecturer as a lecturer in a university is all the behavior of the lecturer who deals with the implementation of his functions and duties in accordance with the criteria determined by the university concerned. The behavior of the lecturer as teaching staff in higher education in implementing learning design is very influential and determines the events of implementation and evaluation of learning outcomes.

\section{Learning Design}

The main activities of system development and learning design in order to design the learning include:

a. Stage identify

1. Identify learning needs and write general learning objectives

2. Conduct a learning analysis

3. Identify early human behavior and characteristics.

b. Development phase

1. Formulate specific learning objectives

2. Develop the benchmark reference test items

3. Develop learning strategies

4. Develop learning materials or materials.

c. The stage of evaluating and revising is stated by arranging the design and carrying out a formative evaluation which includes revision activities. ${ }^{9}$

Based on some of the descriptions above, it can be stated that what must be included in the design of learning is an effort to develop and prioritize learning objectives, both long-term goals and short-term goals, which include: 1) identifying certain prerequisite skills and knowledge needed to achieve purpose, 2) designing learning to encourage student mastery of prerequisite skills, 3) preparing written learning units to support achievement of learning objectives, 4) determining learning strategies to be used, 5) stating levels of cognitive learning, understanding, application, analysis, synthesis, and evaluation, 6) designing the right evaluation.

If the series of performance is realized properly, it will produce a Design of Teaching and Learning Activities (RKBM) or learning design that should be prepared and will be carried out by the teaching staff, thus enabling an effective and efficient learning system.

\section{Learning Implementation}

At the heart of the toolkit is the notion of a learning activity, which we define as consisting of three elements; a) The context within which the activity occurs, this includes the subject, level of difficulty, the intended learning outcomes and the environment within which the activity takes place, b) The learning and teaching approaches adopted, including the theories and models, and c) The tasks are undertaken, which

${ }^{9}$ Morrison GR \& S.M. Ross, Designing Effective Instruction, (USA: Macmillan College Publishing Company, Inc. 1994), 76. 
specify the type of task, the techniques used, associated tools and resources, the interaction and roles of those involved and the assessments associated with the learning activity. ${ }^{10}$ Each lecturer has his own way to determine his learning activities, with the intention of facilitating students to learn and improve the achievement of set goals. Each method was chosen on the basis of confidence in the success of the student and his success in teaching. The selection may be based on certain theories in learning.

According to Reigeluth and Merrill that to develop a learning theory needed clarification that is more detailed and very adequate as the basis for the development of learning theory. There are three main variables that are interrelated learning for development, namely: 1) learning conditions, 2) learning methods, 3) learning outcomes. $^{11}$

Of the three main variables of learning, according to Degeng, the most decisive quality of learning is the learning method variable, as well as this variable requires the performance of lecturers as teaching staff in higher education in taking policies to implement learning strategies in the implementation of learning. ${ }^{12}$

Another study of learning implementation strategies was put forward by Hough which stated that there were nine sequences of learning activities, namely: 1) giving motivation or attracting attention, 2) explaining learning objectives to students, 3) reminding competency prerequisites, 4) giving stimulus, 5) giving learning instructions, 6) giving rise to student appearance, 7) giving feedback, 8) assessing skills, 9) concluding. ${ }^{13}$

The above study explains that the learning implementation strategy relates to the learning process approach in managing learning activities systematically so that it can facilitate students to learn, and the content of the lessons can be mastered effectively and efficiently.

\section{Evaluation of Learning Outcomes}

a. Concept of Evaluating Learning Outcomes

The evaluation concept described by Seels and Richey is the process of determining the suitability of teaching and learning. Evaluation begins with problem analysis which is an important first step in the development and evaluation of learning because the goals and barriers to learning are clarified in this step. Davis argues that

${ }^{10}$ Gráinne Conole \& Karen Fill, "A learning design toolkit to create pedagogically effective learning activities, A learning design toolkit to create pedagogically effective learning activities", Journal of Interactive Media in Education, Vol. 8, 2005, 7-8.

11 C.M Reigeluth dan F.S.Stein, The Elaboration Theory of Instruction, (Hillsdale, N.J : Lawrence Erlbaum Associates, t.t.), 125.

${ }^{12}$ Degeng IN, Ilmu Pengajaran, Taksonomi, Variable, (Jakarta : P2LPTK, 1991), 83. 1976), 137.

${ }^{13}$ AL Hough, An Approach to Curriculum Evaluation, (Colombo Plan Staff College For Technician, 
evaluation is a simple process of giving or assigning values to a number of goals, activities, decisions, performance, processes, people, objects, and many others. ${ }^{14}$

Outcomes assessment is crucially important if study abroad and international experiences are to find a firm foothold in the curriculum and if curricular designers are to make wise decisions that earn the support of the executive leadership of the campus. Research needs to determine how [international service-learning] contributes to a student's readiness and preparedness to learn after returning to the home campus. $^{15}$

Based on the above limitations, it can be concluded that evaluation, in general, can be interpreted as a series of activities systematically to determine something value (goals, activities, decisions, performance, and others) based on certain criteria through measurement or assessment.

\section{b. Functions and Objectives of Learning Outcomes}

According to Sudjana the results of learning are carried out to 1) describe student learning skills so that they can know the strengths and weaknesses in the various fields of study, 2) know the success of the teaching and learning process, how far it is in changing students' behavior towards learning objectives expected, 3) determine the follow-up of the assessment results, and 4) provide accountability from the institution to interested parties.

\section{c. Steps to Arrange an Assessment Tool}

According to Soekartawi, a measuring instrument is said to be of good quality if: 1) testing what is to be tested. In other words, the design of a measuring instrument must be relevant to which assessment function is desired, 2) consists of a series of good measuring instruments, namely a valid, relevant, specific, representative, and balanced measuring instrument. ${ }^{16}$

The sequence of steps in compiling an assessment tool according to Arikunto is as follows: 1) determine the purpose of conducting a test, 2) make restrictions on the material to be used as a test, 3) formulate specific instructional objectives of each part of the material, 4) line all indicators in the preparation table also includes the behavioral aspects contained in the indicator, 5) compiling a specification table that contains the subject matter, the aspect of thinking that is measured along with the balance between the two things. 6) write down the items, based on the indicators already written in the indicator table and the aspects of behavior that are covered.

In making a measuring instrument for the sake of evaluating learning outcomes, a certain procedure must be taken to obtain a good measuring instrument.

${ }^{14}$ Wor. K. Davis, The Management of Learning, (London : McGraw Hill Book Company, 1971), 93.

15 Donald L. Rubin and Paul H. Matthews, "Learning Outcomes Assessment: Extrapolating from Study Abroad to International Service-Learning”, Journal of Higher Education Outreach and Engagement, Vol. 17, No. 2, 2013, 67-80.

16 Soekartawi, Meningkatkan Rancangan Instruksional Untuk. Memperbaiki Kualitas Belajar Mengajar, (Jakarta: Raja Grafindo Persada, 1995), 86. 
Suparman formulated the steps in sequence as follows: 1) determine the purpose of the test, 2) make a specification table for each test (question grid), 3) write test items, 4) assemble the test, 5) write instructions for students about writing the answer and the time needed for each type of test, 6) write the answer key for each test item, 7) test the test, 8) analyze the results of the test, and 9) revise the test. ${ }^{17}$

Based on the description above, it can be understood that the procedures that must be taken in compiling evaluation tools are: 1) determining the information needed, 2) describing the learning objectives according to the defined learning objectives, 3) creating a specification table consisting of a list of behaviors, behavioral weights, the type of test, and the weight of the test, 4) using the condition component in the learning objectives as the basis for compiling the assessment instrument, 5) writing the item by observing the material used, 6) classifying the types of tests and giving an explanation of how to do each type of test, and 7) determine the score for each type of question.

\section{Language skill's}

Arabic as other languages has four language skills. By using the word skill it is understood that the most basic aspects of language are communication tools, and skills are the most basic part when using language. The four majors include listening skill, speaking skill, reading skill, and writing skill. ${ }^{18}$

a. Listening Skill

Listening is the skill of capturing and producing language acquired by hearing. In listening, it usually uses the direct method. This method rule is the initial lesson given by listening or listening training exercises, then followed by exercises saying sounds first, then short words, and finally longer sentences. The sentences are then combined into conversations and stories. The subject matter is written in phonetic notation, not spelling as is usually the case for grammar taught inductively, with composing lessons consisting of reproduction, from those who have been heard and spoken. ${ }^{19}$

Listening is an active process requiring participation on the part of the listener. Listening is a vital skill to acquire pronunciation, vocabulary, word stress, and syntax. Also, the comprehension of messages can be understood through the tone of voice, accent, and pitch. ${ }^{20}$

${ }^{17}$ Atwi Suparman, Desain Pembelajaran, (Jakarta: Departemen Pendidikan dan Kebudayaan, 1991), 73.

18 Imam Makruf, Strategi Pembelajaran bahasa Arab, (Semarang: Need's Press, 2009), 18.

${ }^{19}$ Juwariyah Dahlan, Metode Belajar Mengajar Bahasa Arab, (Surabaya: Al Ikhlas, Cet. I, 1992), 112.

20 MetinTimucin \& Hogai Aryoubi, "Integrating Arts In EFL Curricula: A Focus on Language Listening Skills”, International Journal of Languages' Education and Teaching, Vol. 4, No. 2, 2016, 234. 


\section{b. Speaking Skill}

Speaking is the ability to communicate directly in the form of conversation or dialogue. In general, the purpose of speaking exercises for beginner and intermediate levels is so that students can communicate verbally in simple Arabic. The stages of speaking practice are as follows: In the initial stages, speaking exercises can be said to be similar to listening practice. As stated earlier, in the listening exercise there is a stage of listening and imitating.

The ultimate goal of listening practice is the ability to understand what is being listened to. While the final goal of pronunciation practice is the ability of expression, which is using ideas/thoughts/ messages to others. Both are absolute conditions for reciprocally effective oral communication. ${ }^{21}$

Every linguistic skill has certain targets that will differentiate it from other skills, the targets of speaking are as follows:

1) The learners should articulate the different Arabic sounds, and perform the different types of stress and patterns, in a correct manner.

2) To be able to articulate the approximate and similar sound

3) To know the difference between long and short vowels

4) To express his/her ideas using the correct system of constructing a phrase in Arabic.

5) To acquire linguistic affluence that is equivalent to his/her age, and his/her standard of maturity and ability.

6) To understand some forms of Arabian culture.

7) To be able to think and communicate in Arabic for an acceptable duration of time. $^{22}$

Macaro stressed that effective speakers do not give up or hesitate for too long when they cannot think of how to say something. The researchers believe that to be a good speaker in the Arabic language, students must think positively no matter what others say about them. On the other hand, they must take part in tasks and activities that may encourage them to speak. Additionally, students must be more independent when they are at university. ${ }^{23}$

${ }^{21}$ Ahmad Fuad Effendy, Metodologi Pengajaran Bahasa Arab, (Yogyakarta : Pustaka Pelajar, 2004), 102.

22 Salih Mahgoub EL-Tingari, "Strategies for Learning Second Language Skills: Arabic Speaking Skills in the Malaysian Context", International Journal of English Language Teaching and Linguistics, Vol. 1, No. 1, 2016, 22.

${ }^{23}$ Noor Anida Binti Awang, "Enhancing Arabic Speaking Skills among Malay Students through Group Work Activities", International Journal of Humanities and Social Science, Vol. 3, No. 21, 2013, 213. 


\section{c. Reading Skill}

Reading is considered as a receptive skill, while writing is a productive one. The way to teach these two skills should also be different. Reading is a complex cognitive process of understanding symbols to construct or derive meaning. When we read, we use our eyes to receive written symbols (letters, punctuation marks, and spaces) and we use our brain to convert them into words, sentences, and paragraphs that communicate something to us. Reading can be silent (in our head) or aloud (so that other people can hear). As mentioned above, reading is a receptive skill-through reading we can receive some information. ${ }^{24}$

\section{d. Writing Skill}

Writing is a language skill that is used to communicate indirectly or not face to face with other people. What is meant by writing ability is the skill of making letters (large and small) by copying or imitating writings in the sentence structure. Writing skills that are more important are the ability to write based on the understanding of composition or the ability to compose a language/fabricate. As with reading, writing skills have two aspects, but in different relationships. First, skills form letters and master spelling. Second, proficiency gives birth to thoughts and feelings with writing. ${ }^{25}$

\section{Method}

This research was conducted with a qualitative approach. This research was designed using a case study design, in the form of a study of lecturers who performed their performance. The types of data collected are related to 1) lecturer performance in designing learning which includes: subject identity, learning objectives, subject matter, determination of lecture time, information on learning strategies in class, reference books and other learning resources, 2) lecturers' performance in implementing learning, which includes: delivering outlines of lectures, presenting information including the methods used, establishing educational relations between lecturers and students, using learning media, closing learning activities, 3) lecturers' performance in evaluating learning outcomes which include: planning the determination of things related to student assignment assessment, compiling assessment instruments, designing the middle test, final test, and containing an explanation of the accumulation of all aspects that are used as elements of assessment in order to determine the final value college student.

The data sources in this study were listening and reading lecturers, PBA department heads, and colleagues from PBA lecturers. According to Moleong, the main data sources in qualitative research are words and actions, the rest is additional

24 Sri Mulatsih, Mursid Saleh, Warsono, Issy Yuliasri. "Ideational Meanings of Teachers' Utterances in Reading and Writing Classes", International Journal of Language Teaching and Education, , Vol. 2, No. 3, 20183, 275.

${ }^{25}$ Ahmad Fuad Effendy, Metodologi Pengajaran Bahasa Arab, 140. 
data from written sources, both collected by the lecturers concerned and the departments and faculties.

The research subjects in the context of this case research were lecturers who taught listening and reading courses for the 2017/2018 academic year, totaling 4 lecturers. The number of subjects of this study is used to learn and understand something about the selected case without the need to generalize to all cases. In determining the informants used snowball techniques, but this pattern is not applied in its entirety, because in certain circumstances according to the objectives to be achieved requires researchers determine themselves the next informant who will be found without first determined or notified by previous informants. Data collection techniques in this study were conducted in three ways, namely: in-depth interviews, non-participant observation, and documentation.

The analysis during data collection in the field is done by 1) checking data, 2) organizing data, 3) coding data. While the analysis after the data has been collected is done through three paths, namely: 1) data reduction, 2) data presentation and 3) conclusion/verification. ${ }^{26}$ For the validity of the data, the author uses triangulation with the source that is comparing and checking the degree of trust or information obtained through time and different tools in qualitative research.

\section{Result and Discussion}

Performance of lecturers in designing learning language proficiency courses

a. Listening Course

In designing the subject course, the lecturer of the course has made SAP the same course he took care of in this semester, but he said he did not know whether the other lecturers who taught the same subjects also made SAP, to know that those who teach eyes This lecture is two lecturers, He said that: "Before I teach, I first made SAP, this is important I do as a guideline in implementing listening learning," but I admit that in making this SAP I did not coordinate with other lecturers. In making this SAP I do it myself and of course, based on my ability ".

Furthermore, the caregiver of the course is not one hundred percent guided by the curriculum in the faculty, there are some things that are adopted according to the ability of students in the classroom, one of which is a material problem. Some of the topics of discussion he adopted from the curriculum that he considered were in accordance with the abilities and needs of students.

Based on the SAP istima document, some of the components contained in the syllabus are as follows: course identity, basic competencies, the main material, and a description of the main material, learning experience, indicators, assessment, media, and teaching tools, and references. (documentation of listening)

${ }^{26}$ Michael Quinn Patton, Qualitatife Evaluation Methods, (Beverly Hill : Sage Publication, 1987), 331. 


\section{b. Reading Course}

In designing reading skills learning courses namely reading, lecturer of the course he said that before the implementation of the course learning activities reading for one semester, he has made learning design in the form of SAP that he made based on the knowledge that he mastered, and already done before, even the design of the course is basically the same as the previous one, only updated about the lecture schedule. and he is always guided by the curriculum in the Arabic Language Education Department of the UIN STS Jambi, particularly regarding the standards of competence, basic competencies, and subject matter. Because this has been stipulated in the faculty curriculum so that lecturers are not given the authority to change. To direct the learning process, FW practices the arrangement of the material contained in SAP, each meeting is discussed one or two materials according to the time available.

Learning material contained in SAP, in the form of subjects in accordance with the curriculum in the PBA department, and for more detailed elaboration contained in the teaching material that was set though not perfect. While the test for each subject matter according to FW he never fit in the design of learning, he only did it when the learning process took place, and for assessment FW took from several components, namely from the results of the assignments given, from mid semester exams, final semester exams, and from the presence of students following the lecture process.

\section{Performance lecturers in implementing language proficiency course learning}

\section{a. Listening Course}

The implementation of istima 'learning courses carried out by $\mathrm{Mr}$. KU in one semester ranges from 14 times face to face. To know the realization, it can be seen from his statements as follows: I usually carry out the learning process in this course by using the tadribat istimaiyah method, as well as lecture and question and answer methods. The tadribat istimaiyah method is a method of training students in listening to simple Arabic texts, then students are asked to identify and differentiate the types of letters that are close together, give meaning to a particular vocabulary, understand the contents of the message, and express the contents of the message in the form of spoken language and writing. While the lecture method I used in the first meeting was when introducing myself as needed while doing student attendance, followed by informing SAP. The question and answer method are carried out on the sidelines of the lecture method and tadribat istimaiyah.

Learning media used in the istima learning process are language laboratories, tape recorders, cassettes, DVD players, laptops, infocus, blackboards, and board markers. Of the many media both audio and audiovisual, KU's father uses audio more often, namely tape and cassette than audio-visual, this is what he said: "I often use audio rather than audio visual because audio (tape) is very compatible with istima material 'also because equipment that helps such as materials and VCD is rather difficult to obtain when compared to cassettes. If the tapes to train students' hearing 
from beginner to a high level are very easy to obtain and are provided by the department. Even so, it does not mean that audiovisual is not used at all, I still use VCD even though sometimes the content is not in accordance with syllabus but it is more interlude or entertainment so students are not saturated.

At the end of the learning process listening usually provides an explanation of the material discussed especially if students feel many difficulties, both in the form of understanding vocabulary, understanding texts that are heard or difficulties in summarizing the main ideas.

Among the efforts made by Mr. KU to motivate his students to practice listening to Arabic is always to advise students to play Arabic videos, whether in the form of videos of songs, chanting, drama or others. And sometimes Mr. KU gives video files to students to see in their homes.

The first observation of the learning process maharatul istima ', Mr. MT entered the class by saying hello, then asked whether this student was really a participant in the maharatul istima 'course he was teaching. After most of the students answered "yes", then he began to explain about the SAP he had made after he briefly introduced himself and attended his students who at that time from 27 students written on the attendance list only 24 students attended, three people did not enter without information, this activity lasted 55 minutes. In explaining SAP, he began by mentioning the competencies that must be achieved by each student in this mahima ul istima 'course. After he explains the competencies and indicators, the next is, material, learning experience, assessment, and tools and sources of teaching.

In the second observation, Mr. MT entered by saying greetings and then attending the student by name one by one. After completion, Mr. MT invited the students to get ready to listen to a simple reading text that he would read and then students were asked to record vocabulary that had no known meaning. Mr. MT read a simple reading text about a'malul yaumiiyah, all students watched him attentively and occasionally they wrote vocabulary that they did not know, MT repeated the reading for the second. After that, let the students ask for the vocabulary that they have not understood before giving questions about the differences in the sounds of the letters that are close together and about understanding the contents of the text that he read earlier. There were three students who asked about the meaning of the word and answered MT briefly without any lengthy explanation.

The third observation, at this meeting, Mr. MT had prepared a video to be played and played to students, the topic to be discussed at this meeting was at-tarwih fil Islam, a relatively long reading text and had more complex expressions than the previous meeting.

After attending and instructing students to prepare it, MT began playing the video and explained a little that the material this time was relatively more difficult and the content of the text was relatively more complex, so at this stage pay close attention and note if there are mufradat that have not been understood, then MT played back the video, but this time it was not played in its entirety but each one paragraph while 
discussed and students are given questions to measure their understanding of the paragraph, and so on until it's finished.

\section{b. Subjects of Reading}

The implementation of reading learning conducted by Mr. FW in one semester ranges from 16 times face to face including in mid-semester and final semester examinations. To find out the realization can be seen from the statement and the description as follows: the teaching process that I did use the qira'ah method, assignment and practice directly in the classroom, and the question and answer method. In more detail, he stated that in the first meeting, besides informing about the objectives of the course, learning methods, materials, and methods of assessment, he also conducted a pre-test. This was done to measure the initial abilities of students so that I would not provide material that was far from their abilities for both low and high. Also as a measure of the progress, they achieved after the lecture was completed at the end of the semester.

The media used by Mr. FW in the learning process of the Maharah al-Qira'ah course is commonly used tools such as infocus, blackboard, markers, books related to qira'ah sya'iah, and Arabic-Indonesian dictionaries. Observing the author in the field, Mr. FW entered the class 10 minutes late, then he said his greetings and then delivered the material to be discussed at this meeting as he had delivered at the previous meeting. Then he asked the students whether they had copied the qiraah material he had submitted last week, and it appeared that all students answered "yes already". Furthermore, Mr. FW wrote the theme that will be discussed on the board, to the students, they were asked to open their respective potencies, then Mr. FW told one by one the students to read the qiraah material in a religious manner about 20 minutes.

\section{Performance of lecturers in evaluating language proficiency course learning}

a. listening Course

In evaluating, Mr. KU stated that the evaluation of student learning outcomes in this istima 'course was carried out in accordance with the evaluation rules and regulations of the Department of Arabic Language Education, Tarbiyah Faculty, UIN STS Jambi. In his interview he told the author as follows: the components that I used in the assessment in determining the final grades of students apart from the midsemester grades and the end of semester grades, as well as assignments.

For the mid-semester exam and the end of the semester Mr. KU said: I scheduled the mid-semester exam at the eighth meeting held in the labor language room with the material they had studied, with 10 questions, while I always carried out the semester exams outside the exam schedule determined by the faculty, this is considering the examination in the language laboratory room, and I schedule one week before the final semester exam begins. 
The provision of whether or not students take part in the final semester exams depends on their attendance in the lecture process, if their attendance is less than $80 \%$ in one semester, then the person may not take the final exam, except if the person meets the lecturer and explains the reason for his absence and the lecturer can accept the reason if not, it means that the person concerned is not entitled to take the final examination, so the possibility of not passing is very large.

Submitting the final grade to the academic section conducted by KU is always on time for the submission deadline, this is done so that there is no same value given by the academic section, because it is in accordance with the circular letter from the dean 1, that if the lecturers set the deadline do not submit a list of grades of students, the value will be taken over by the department, and given sanctions not guiding and testing the thesis and compensation in the following semester.

\section{b. Subjects of Reading}

Mr. FW stated that the evaluation of student learning outcomes in this muthalaah course was carried out in accordance with the evaluation requirements of the faculty as he said: "The four components that I usually use in determining the final grades of students in this learning, namely the collection of assignments during lectures, mid-semester exam scores, final semester exam scores, and participation values in accordance with applicable provisions that refer to ISO 9001 standards.

In preparing the implementation of the assessment of the component, Mr. FW did it as follows: a) for attendance value including the participation of Mr. FW always gave a sign to each student who entered and did not enter for several reasons. b) for mid-semester exam preparation, Mr. FW does not make item questions in detail, because the exam is carried out verbally, the preparation is only with attendance and syllabus courses, so questions are developed by FW when in the classroom.c) for exam questions at the end of the semester, Mr. FW gave assignments to students and was collected during the exam schedule for the course. d) for tasks already prepared in advance, namely sometimes taken from several references, or sometimes he himself made it.

\section{Conclusion}

Performance of Arabic education lecturers faculty of Tarbiyah UIN STS Jambi in learning language devotion that lecturer have not maximized the potential in giving lectures, coupled with the preparation of SAP courses that are lacking this is seen in 1) the design of learning made by lecturers listening and reading in the form of SAP, only briefly explains about several components, namely the identity of the course, learning outcome indicators, lecture method, assessment, and bibliography, mentions several reading sources used in the listening learning process and reading, 2) the implementation of learning include preliminary activities in the form of mentioning lecture material to be studied in one semester, core activities by applying patterns learning that further activate students to practice expressing their ideas in writing and understanding the texts that are played. And closing activities, in the form of 
Arabiyât Jurnal Pendidikan Bahasa Arab dan Kebahasaaraban, 6 (2), 2019

delivering conclusions from the material that has been discussed, 3) the evaluation of learning outcomes is an activity of measuring the level of success and ability of students in the learning process.]

\section{REFERENCES}

Anida, Noor. "Enhancing Arabic Speaking Skills among Malay Students through Group Work Activities", International Journal of Humanities and Social Science, Vol. 3, No. 21, 2013.

Arikunto, Suharsimi. Dasar-Dasar Evaluasi Pendidikan. Jakarta: Bumi Aksara, 2015.

Atwi, Suparman. Desain Pembelajaran. Jakarta: Departemen Pendidikan dan Kebudayaan, 1991.

Azmahani Aziza, Azmahani., Khairiyah M. Yusof., Jamaludin M. Yatim. "Evaluation on the Effectiveness of Learning Outcomes from Students' Perspectives”, International Conference on Teaching and Learning in Higher Education (ICTLHE), in conjunction with RCEE \& RHED, 2012.

Conole, Karen Fill Gráinne. "A learning design toolkit to create pedagogically effective learning activities", Journal of Interactive Media in Education, Vol. 8, 2005.

Dahlan, Juwairiyah. Metode Belajar Mengajar Bahasa Arab. Surabaya: Al-Ikhlas, t.t, Cet I.

Davis, Wor. K. The Management of Learning. London: McGraw Hill Book Company, 1971.

Degeng, IN. Ilmu Pengajaran, Taksonomi, Variable. Jakarta: P2LPTK, 1991.

Efendi, Ahmad Fuad. Metodologi Pengajaran Bahasa Arab, Yogyakarta: Pustaka Pelajar, 2004.

Eltingari, Salih Mahgoub. "Strategies for Learning Second Language Skills: Arabic Speaking Skills in the Malaysian Context", International Journal of English Language Teaching and Linguistics, Vol. 1, No. 1, 2016.

Hough, AL. An Approach to Curriculum Evaluation. Colombo Plan Staff College For Technician, 1976.

Makruf, Imam. Strategi Pembelajaran bahasa Arab. Semarang: Need's Press, 2009.

Morrison, GR \& S.M. Ross. Designing Effective Instruction. USA: Macmillan College Publishing Company, Inc. 1994.

Mulatsih, Sri Mursid Saleh., Warsono., \& Issy Yuliasri. "Ideational Meanings of Teachers' Utterances in Reading and Writing Classes", International Journal of Language Teaching and Education, Vol. 2, No. 3, 2018.

Prasetio, Arif Partono. “Lecturers' Professional Competency and Students' Academic Performance in Indonesia Higher Education", International Journal of Human Resource Studies, Vol. 7, No. 1, 2017.

Reigeluth, C.M., \& F.S. Stein. The Elaboration Theory of Instruction. Hillsdale, N.J.: Lawrence Erlbaum Associates, t.t. 
Arabiyât Jurnal Pendidikan Bahasa Arab dan Kebahasaaraban, 6 (2), 2019

Rubin, Donald L., and Paul H. Matthews. "Learning Outcomes Assessment: Extrapolating from Study Abroad to International Service-Learning", Journal of Higher Education Outreach and Engagement, Vol. 17, No. 2, 2013.

Sastrawijaya, T. Proses Belajar Mengajar di Perguruan Tinggi, Jakarta: Dirjen Depdikbud, 1988.

Soekartawi. Meningkatkan Rancangan Instruksional Untuk Memperbaiki Kualitas Belajar Mengajar. Jakarta: Raja Grafindo Persada, 1995.

Suryaman. "Indonesian Private University Lecturer Performance Improvement Model to Improve Sustainable Organization Performance", International Journal of Higher Education, Vol. 7, No. 1, 2018.

Tarigan, Henry Guntur. Membaca Sebagai Suatu Keterampilan Berbahasa. Bandung: Angkasa, Cet VII, 1979.

Timucin, Hogai Aryoubi Metin. "Integrating Arts In EFL Curricula: A Focus on Language Listening Skills", International Journal of Languages' Education and Teaching, Vol. 4, No. 2, 2016.

Uno, Hamzah B. Profesi Kependidikan. Jakarta: Bumi Aksara, 2008.

Yusrizal. "Performance Assessment of State Senior High School Teachers Aged 56 Years and Above", International Journal of Instruction, Vol. 11, No. 1, 2008.

Zais, Robert S. Curriculum Principles and Foundation. Newyork: Harper \& Row Publisher, 1976. 